УДК 347.4

В. Зверховська,

кандидат юридичних наук, викладач кафедри патологічної анатомії, судової медицини та права

Вінницького національного університету імені M.I. Пирогова

\title{
ПРАВОВЕ РЕГУЛЮВАННЯ ПОПЕРЕДНЬОГО ДОГОВОРУ ЗА ЦИВІЛЬНИМ ЗАКОНОДАВСТВОМ УКРАЇНИ
}

В умовах ринкової трансформаціі економіки України, розвитку цивільного обороту, що оснований на сукупності суб'єктів цивільно-правових відносин, особливе значення має частина законодавства України, котра призначена регулювати широкий спектр відносин щодо організації та ведення цивільно-майнового обігу. Специфіка цієї сфери діяльності в тому, що вона спрямована на регулювання зобов'язальних відносин. У процесі їх функціонування, виробництва матеріальних та інших благ учасники цивільно-правових відносин вступають між собою в економічні відносини, котрі постійно модифікуються та змінюються по мірі розвитку виробничих сил і характеру потреб суспільства. Ці зміни виражаються в різних формах володіння факторами виробництва та його продуктами, в економічних інтересах різних суб' $є$ тів, проникають у процеси виробництва, а також зумовлюють особливості управління цими процесами. Названі вище процеси суб'єкти цивільно-правових відносин узгоджують завдяки договорам, що є одним із найпоширеніших підстав виникнення зобов'язань. У юридичній літературі нормативно-правовий договір традиційно визначається як двостороннє або багатостороннє погодження між суб'єктами, яке містить норми права. Розуміння договору як універсального джерела права відомо ще з часів античності. Як відзначається в літературі, погодження (consensus) народу римські юристи вважали універсальним правом, утворювальним чинником, зараховуючи до договору як закони, так і звичаєве право. Загалом же уявлення про нормативний договір як джерела права пов'язано 3 доктриною природного права, розумінням норми в європейському середньовіччі, визначаючи його як єдине джерело позитивного права й держави, оскільки конструкції уявляли собою нормативний договір між королем і прилеглими («Великая Хартия вольностей 1215 г., Золотая булла 1222 г.» тощо).

Потреби сучасного цивільного обороту, який усе більше набуває якостей розмаїтості й інтенсивності, сприяють розвитку нових видів договорів, у яких скомбіновано різноманітні юридичні елементи. Підвищений інтерес до дослідження договірних відносин часом виключає зі свого поля зору деякі інститути. Серед таких інститутів нині опинився інститут попереднього договору, який не відрізняється достатністю нормативного регламентування й, можливо, саме із цих причин не здобув грунтовної уваги сучасних учених, хоча на практиці цей договір широко використовується. Його, зокрема, досліджували В.В. Вітрянський, M.I. Брагінський, Р.А. Майданик, С.М. Бервено, Е.В. Богданов, О.С. Йоффе та інші. Однак відсутність системності досліджень зумовлює те, що наявні висновки характеризуються несистемністю й подекуди мають суперечливий характер [1]. Тому мета дослідження цього питання полягає в аналізі норм чинного законодавства про зміст і форму попереднього договору та пошуку шляхів його вдосконалення. 
Комплексне дослідження інституту попереднього договору дає змогу виділити значну кількість колізій і невирішених питань під час реалізації норм цього інституту. Недостатня розробленість положень попереднього договору тягне за собою неоднозначність у підходах до його розуміння. Невирішеним до останнього часу залишається питання про можливість визнання за сторонами переважного права на реалізацію власного інтересу за попереднім договором. Поняття форми попереднього договору також не знаходить однозначного розуміння ні в роботах цивілістів, ні в правозастосовній практиці. Проблема необхідності й достатності істотних умов попереднього договору ані в працях цивілістів, ані в судовій практиці не знаходить однозначного вирішення. Із цього випливає, що недостатність уваги до інституту попереднього договору в цивілістиці тягне за собою відсутність стійкого підходу й у практиці правозастосування. Усе вищевикладене й зумовлює актуальність дослідження.

У правовій доктрині є досить значна кількість робіт учених, які на різних етапах розвитку цивілістичної думки присвячували праці насамперед дослідженню договору загалом і водночас деякою мірою приділяли увагу попередньому договору. Внесок у розвиток теми в дореволюційний період зробили такі вчені, як Є.В. Васьковський, Д.І. Мейер, Й.О. Покровський, B.I. Синайський, П.П. Цитович, Г.Ф. Шершеневич. У радянський період і на сучасному етапі найбільшої уваги інституту попереднього договору приділено в працях українських i російських учених: І.Б. Новицького, Є. Годеме, С.М. Братуся, В.П. Грибанова, О.С. Йоффе, О.Ю. Кабалкіна, О.О. Красавчикова, монографічному дослідженні С.М. Бервено, наукових працях С.С. Алексєєва, О.А. Беляневич, І.А. Бірюкова, Д.В. Бобрової, Т.В. Боднар, М.І. Брагінського, В.В. Вітрянського, Б.М. Гонгало, О.В. Дзери, I.О. Дзери, А. Днєпрова, В.В. Луць, А.В. Луць, Н.С. Кузнєцової,
А.М. Кучер, О.М. Клименко, Р.А. Майданик, Н.I. Майданик, Є.О. Мічуріна, I.P. Назарчук, О.М. Садікова, О.П. Сергєєва, К.І. Скловського, Є.О. Суханова, Ю.К. Толстого, Є.І. Фурси, С.Я. Фурси, в працях окремих іноземних правознавців: В. Ансона, Д. Трейтела та ін.

Стрімкий розвиток майнового обороту й, відповідно, реформування цивільного законодавства викликані фундаментальними політико-правовими змінами 90 -х років XX століття, зумовили значне зростання ролі попереднього договору в сучасному цивільному праві України.

3 погляду правової природи попередній договір завжди консенсуальний. Він безоплатний, але майновий, спрямований на організацію товарообороту й у разі відмови однієї зі сторін його виконати забезпечений обов'язком стягнення збитків, понесених другою стороною у зв'язку з ухиленням чи відмовою від укладення основного договору. Попередній договір є двостороннім, за яким обидві сторони зобов'язані укласти основний договір. Однак це не означає, що сторони не можуть укласти договір, який покладає обов'язок укласти основний договір лише на одну зі сторін $[2$, с. $5,9,14]$.

Попередній договір $€$ підставою (внутрішнім чинником) обмеження принципу свободи договору. Основний договір, що укладається на підставі попереднього договору, належить до групи договорів (разом із договором, який укладається за результатами проведених торгів), обов'язковий порядок укладення якого випливає 3 добровільно прийнятого зобов'язання.

Укладенню основного договору передує наявність попереднього договору як специфічного виду зобов'язань - зобов'язання укласти основний договір, що виникає зі складного юридичного складу: передбаченого законодавством добровільно взятого зобов'язання (юридичного факту, що дозволяє вимагати укладення основного договору) та оферти сторони, заінтересованої в укладенні основного 


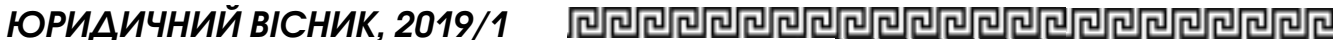

договору. Змістом цього зобов'язання з попереднього договору є дії зобов'язаної сторони з укладення договору на умовах, погоджених сторонами в процесі його укладення, а в разі виникнення розбіжностей визначених судом $[2$, с. $5,9,14]$.

У зв'язку з цим за своєю сутністю попередній договір є добровільно взятим зобов'язанням на укладення договору в обов'язковому порядку, що дозволяє вимагати укладення основного договору [3, с. 35-40].

Правовий статус та особливості укладення попереднього договору регулюються як Цивільним (далі - ЦК), так і Господарським (далі - ГК) кодексами України. Проте поняття попереднього договору надає саме ЦК України. Частина 1 ст. 635 ЦК України визначає, що попереднім є договір, сторони якого зобов'язуються протягом певного строку (у певний термін) укласти договір у майбутньому (основний договір) на умовах, установлених попереднім договором.

Водночас ГК України практично дублює положення ЦК України, встановлюючи лише певні особливості укладання попередніх договорів між господарюючими суб'єктами. Термін укладення основного господарського договору дорівнює одному року з моменту укладення сторонами попереднього договору. Натомість ЦК України не встановлює жодних термінів для укладення основного договору й містить лише вказівку на можливість обмеження такого строку законом. На практиці ж питання наявності чи відсутності терміну, протягом якого має бути укладений основний договір, залежить виключно від суб'єктного складу та характеру природи самих правовідносин: є вони цивільними або господарськими. Загалом існують також й інші розбіжності в регулюванні, проте з урахуванням ч. 5 ст. 182 ГК Украіни [4, с. 97] відносини щодо укладення попередніх договорів регулюються ЦК України з урахуванням особливостей, передбачених ГК України.
Попередні договори $€$ різновидом переддоговірних правочинів, мотив в укладенні яких зазвичай полягає в тому, щоб «створити між собою правовий зв'язок не настільки сильний, як правовідношення з основного договору» [5, с. 21]. Попередній договір також $€$ одним із двох видів переддоговірних правочинів, які прямо вказані українським правом. Тому зміст подібних договорів становить усі умови остаточного (майбутнього) договору, однак він передбачає, що в силу певних обставин сторони укладають остаточний договір пізніше. Обставиною може виступати, наприклад, придбання майна, що $€$ об’єктом договору, через певний час після укладення попереднього договору. Укладення такого договору нерідко викликає недоцільність укладання остаточного договору на цей момент, зокрема правочин, у якому між моментом укладання й моментом виконання $€$ досить великий часовий розрив [6].

Один із авторитетних науковців, Г.Ф. Шершеневич, указував, що попередній договір є організаційним договором. Мета його полягає в організації укладення будь-якого договору в майбутньому. Попередній договір застосовують у тих випадках, коли сторони майбутнього договору домовилися про всі істотні умови майбутнього договору, але існують перепони до укладення (наприклад, покупець ще не має достатньої грошової суми для оплати, сторони не мають усіх документів, необхідних для оформлення договору тощо) [7, с. 324].

У літературі звертається увага на особливість попередніх договорів, яка полягає в тому, що подібні правочини не $є$ різновидом будь-якого типу цивільно-правового договору й загалом випадають із їх загальноприйнятої класифікаціі. Сутність і зміст правовідносин із попереднього договору якісно відрізняють його від усіх інших договорів. Попередній договір є особливим договірним зобов'язанням, яке опосередковує самостійне коло відносин щодо 
укладання в майбутньому основних договорів, що вимагає спеціального правового регулювання подібного правового інституту.

Попередній договір не спрямований безпосередньо на регулювання економічних (майнових) відносин між учасниками. Окремі автори вважають, що «швидше він регулює «організаційно-юридичні» відносини між ними».

У цьому контексті цілком слушно відзначається, що більшість договорів є підставою для виникнення зобов'язань із передачі майна у власність або в користування, виконання робіт, надання послуг тощо. Однак зазначена група договорів не має такої завершеності, вони лише містять обов'язковий припис сторонам укласти певний конкретний договір у майбутньому: договір перевезення, підряду, купівлі-продажу тощо.

У зв'язку з цим виділяють два етапи існування зазначених правовідносин: 1) укладання попереднього договору, де сторони визначають предмет договору, встановлюють ціну, строк укладання основного договору та інші умови; 2) укладання основного договору на умовах, визначених у попередньому договорі [9, с. 33].

Типовим різновидом цього договору $€$ традиційно відомий із давніх часів вітчизняному праву договір купівлі-продажу, згідно з яким сторони зобов'язуються у визначений ними строк укласти договір купівлі-продажу (наприклад, щодо речі, якої поки немає в продавця або щодо якої він не має права власності або воно обтяжене правами інших осіб) [10, с. 159].

Іншим прикладом застосування попереднього договору $€$ довгостроковий договір про організацію перевезень як різновид так званих «генеральних» договорів, на підставі й на виконання яких сторони потім укладають цілу низку конкретних однотипних (локальних) договорів. Це наприклад, спрямовані на організацію перевезень вантажів річні та аналогічні їм договори перевізників із вантажовідправниками, які виступають підставою для наступного укладання договорів перевезень проектних вантажів [10, с. 159]. За цим договором, перевізник зобов'язується в установлені строки приймати, а вантажоволоділець - пред'явити до перевезення вантажі в повному обсязі. Сторони можуть також визначити строки, порядок розрахунків тощо.

Попередні договори застосовуються й в інших сферах діяльності. За допомогою попереднього договору підрядник і замовник регулюють свої відносини з підготовки укладання в майбутньому договору будівельного підряду, обумовлюють предмет майбутнього договору, строк його укладення, необхідність надання документів тощо.

У літературі звертається увага на відомі правозастосовній практиці випадки, коли основний договір водночас виступатиме й договором попереднім. У цьому випадку згідно з умовами попереднього договору сторони повинні будуть у майбутньому укласти ще один основний договір.

Ідеться про придбане переможцем аукціону право на укладання договору оренди нежилого приміщення. Зазначене право кредиторам посвідчене належним чином актом, яким зафіксовано, що договір оренди повинен бути оформлений протягом десяти днів.

За своєю правовою природою спірний правочин уважається договором купівлі-продажу на оренду нежилого приміщення й водночас попереднім договором на укладення договору оренди нежилого приміщення [11, c. 34].

Як й інші договори, попередній договір обов'язково передбачає узгодження всіх його істотних умов, до складу яких входить і певний набір істотних умов остаточного договору. Відсутність хоча б однієї із цих умов виключає можливість звернутися 3 позовом про спонукання контрагента за попереднім договором укласти основний договір. Відповідно, відсутні підстави в подібних випадках і для стягнення 3 контрагента збитків, заподіяних унаслідок 


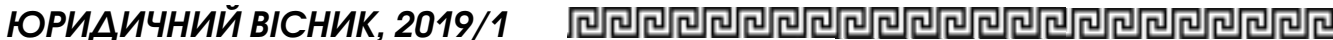

ухилення другої сторони від укладення договору [12, с. 234].

Попередній договір відіграє фактичну і юридичну роль у процесі формування договірного відношення. Серед питань, пов'язаних із попереднім договором, необхідно звернути увагу на ï зв'язок із переговорами сторін, які передували укладенню договору.

Ключові слова: попередній договір, правове регулювання, зміст договору, цивільні правовідносини.

У статті розглядається порядок та особливості правового регулювання попереднього договору в Украіні, основні вимоги до попереднього договору й перспективи розвитку відповідних правовідносин.

В статье рассматривается порядок и особенности правового регулирования предварительного договора в Украине, основные требования $к$ предварительному договору и перспективы развития соответствующцих правоотношений.

The article discusses the procedure and features of the legal regulation of the preliminary contract in Ukraine, the basic requirements for the preliminary contract and the prospects for the development of relevant legal relations.

\section{Література}

1. Скакун Ю.Є. Зміст попереднього договору. Право України. 2007. № 5.

2. Попова Е.А. Заключение договора в обязательном порядке : автореф. дисс. ... канд. юрид. наук. Минск, 2004. С. 5, 9, 14.

3. Бервено С.М., Майданик Р.А. Понятmя $i$ зміст попереднього договору за изиільним законодавством України. Бюлетень Міністерства юстииї України. 2005. № 10 (48). С. 35-45.

4. Хозяйственный кодекс Украины от 16.01.2003 по состоянию на 1 сентября 2012 года. Харьков : Одиссей, 2012. С. 97.

5. Днепров A. Что такое предварительный договор? Юридическая практика. 2004. № 8 (322). C. 21.

6. Степанова О. Предварительный договор. Финансово-правовой абонемент «Предпринимательская практика: вопрос - ответ». 1999. Bыn. 3.

7. Шершеневич Г.Ф. Учебник русского гражданского права. Москва, 1995. С. 324.

8. Днепров А. Что такое предварительный договор? Юридическая практика. 2004. № 8 (322). C. 21.

9. Богданов Е.В. Предпринимательские договоры. Москва : Книга сервис, 2003. C. 33

10. Суханов Е.А. Гражданское право: в 2 m. 2-е изд., перераб. и доп. Москва : БЕК, 2003. Том 2. Полутом 1: учебник. С. 159

11. Богданов Е.В. Предпринимательские договоры. Москва : Книга сервис, 2003. C. 34 .

12. Брагинский М.И. Разноотраслевые договоры. Брагинский М.И., Витрянский В.В. Договорное право. Москва : Статут, 2003. Кн. 1: Общие положения. С. 234. 